\title{
Designing and constructing multi-types of physiotherapy specializations centre through applying a novel approach of quality function deployment (QFD) and Kano Model
}

\author{
Zain Alshami ${ }^{1}$, Atheer Alnawayseh ${ }^{1}$, Eman Frehat ${ }^{1}$ and Mohammed Rawashdeh ${ }^{2 *}$ \\ ${ }^{1}$ King Hussein Medical City, Jordan \\ ${ }^{2}$ SDPM International, Kuwait
}

\begin{abstract}
Designing and Constructing Multi-types of Physiotherapy Specializations Centre through Applying Quality Function Deployment (QFD) and Kano Model. It is a splendid conducted research involving a smashing combination between seven specialties in two countries: Kuwait and Amman. The specialties are: rehabilitation doctors, physiotherapists, biomedical engineers, staff nurses, chemical engineers, architectural engineering and industrial engineers. This research represents a case study of designing and building a new specialized rehabilitation and physiotherapy hospital. In the concept design stage we utilized the industrial engineering principles representing by QFD, Kano Model to collect information about the required departments and medical equipment to be installed. We applied QC tools representing by control chart and histogram to verify the accuracy of the provided information before presenting it to the architect to prepare the concept design drawings. By applying QFD and Kano Model, we build a so called House of Quality (HOQ).This HOQ represents the perspectives of rehabilitation doctors, physiotherapists, biomedical engineers, staff nurses, and chemical engineers regarding the departments and medical pieces of equipment quantities in the hospital. This novel approach deeply illustrated the end users necessities and reflected an efficient design and project time saving.
\end{abstract}

\section{Introduction}

Considering the international gauntlets in manufacturing world, firms are obliged to improve their business processes to stay competitive. To obtain this target, companies must work with its staff partners to improve the company's total performance [1].

Determining the connection links among the hospital buildings which have sophisticated construction and peculiar locative relationships is quite troublesome [2].

The hospital structure which require specialization in locative links solutions during delineation and self- invention through the developing technology should last and any hard circumstances.

Building a new infirmary presents chances to resemble the layout of the infirmary structure with the required logistical concept. In that situation the layout should be appropriate to handle with all the flows of clients and merchandise now and in the future [3].

This research combined Quality Function Deployment (QFD) and Kano Model to systematically design a physiotherapy and rehabilitation center.

In the literature, there were a number of researches used QFD in rehabilitation to : (1) achieve how these mechanism can be best used in a multi discipline rehabilitation engineering team and, (2) establish measures of outputs for the patient which reference the inputs to the rehabilitation engineering process and the goodness of service and products provided to the patient [4].

In 2005, Gonzalez et al, constructed optimal activity-based costing (ABC) model utilizing baseline data from 5 different Spanish hospitals through applying QFD. He argued both the clients' contentment benchmarking operation in QFD and the advantages of hierarchical benchmarks in determining the areas of strategic vying. He presented a case study to demonstrate the used approaches: benchmarking and QFD to get the optimal ABC [5].

In 2008, Ulrich et al, conducted a new and more intensive search for tough empirical studies that connect the delineation of hospital physical environments with healthcare outputs. The review put up with a two-step process, comprising an extensive search for present literature and a screening of each particular study for the relevance and quality of evidence [6]

Determining medical service improvement priority by integrating the refined Kano model, Quality function deployment and Fuzzy integrals.

In 2008, Tsai et al., used QFD to excerpt bottleneck techniques in delineation of an assistive device. A case study was conducted and a new power-assisted wheelchair was developed to overcome the insufficiency of traditional manual wheelchairs [7].

In 2012, saka et al. investigated Education, IS experience, age, attitude towards change, business title, sex and working unit of the

Correspondence to: Mohammed Rawashdeh, SDPM International, Kuwait, E-mail: m_rawashdeh2004@yahoo.com

Key words: Kano model, House of Quality (HOQ), Quality Function Deployment (QFD)

Received: August 29, 2016; Accepted: October 22, 2016; Published: October 25,2016 
Alshami Z (2016) Designing and constructing multi-types of physiotherapy specializations centre through applying a novel approach of quality function deployment (QFD) and Kano Model

hospital as the potential determinant of the medical users' anticipation. Information about medical client expectations is gathered by the "Expectation Questionnaire" developed for this study.

Anticipation information is utilized for estimating the Expectation Meeting Ratio (EMR) with the evaluation framework also developed for that research [8].

In 2013, Akdag et al., characterized the utilization of QFD in the private healthcare sector in Turkey. He presented a case study integrating the SERVQUAL and QFD to enhance its quality.

He utilized a SERVQUAL-type of scouting and distributed a total of 250 scouting and 210 of them were received. Usable responses were 170 , comprising a response rate of 68 percent.

He found that the behavior and attitude of crew has the highest weight outcome, meaning that when demeanor and attitude of staff is improved there will be almost 25 per cent of improvement in the infirmary. Another result was that there is strong connection among proficiency of physician, demeanor and attitude of staff, and having sufficient modern equipment [9].

\section{Methodology}

A group of biomedical and chemical engineers conducted a case study methodology by applying a survey on group Hospital Clients (HC) of rehabilitation doctors, physiotherapists, biomedical engineers, staff nurses, chemical engineers, architectural engineering and industrial engineers. It initiated from characterizing $\mathrm{HC}$ necessities (Voice of Clients) (VOC) to receive their perspectives on the QFD matrix which called also House of Quality (HOQ) case study pattern as expounded in Figure 1.

The HOQ is the major delineation gadget in the QFD process. It is a conceptual chart that supplies the means for inter functional delineation and connection of client necessities and technical responses. In the HOQ, The procedure to build the HOQ is:

- List client necessities (whats),

- List technical features (hows),

-Establish a relevance matrix between whats and hows,

- Establish an interrelationship model between hows,

- Establish prioritized client necessities,

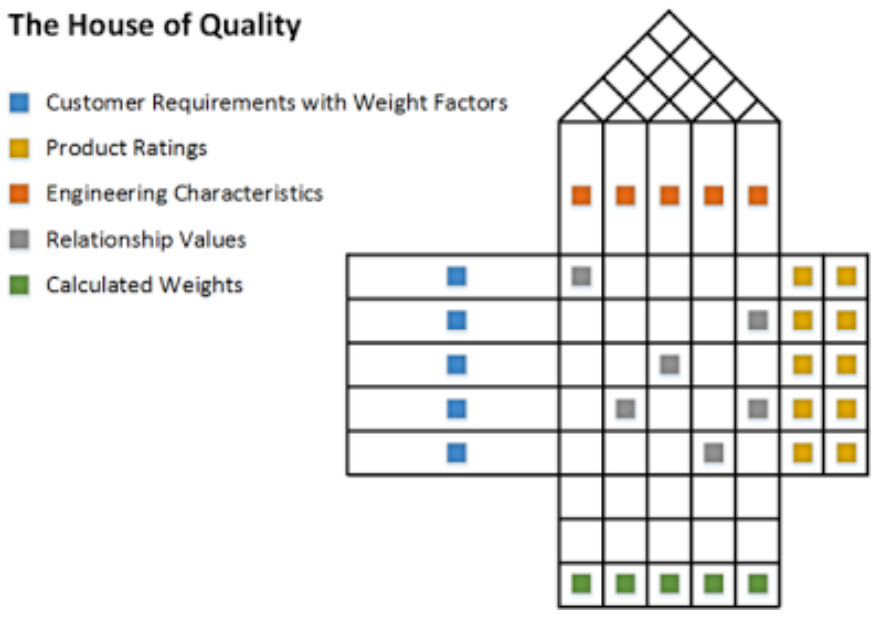

Figure 1. House of Quality (HOQ) [10].

\section{- Establish prioritized technical features.}

Establishing client necessities is the most pivotal phase in QFD procedure. In this research, the major client necessities (WHATs) have been blossomed from applying Kano model through a survey formed by interviewing HC.

The Kano Model of client contentment rates service characteristics according to how they are comprehend by clients and their impact on client contentment. These ratings are helpful for instructing delineation rulings in that they point out when good is good enough, and when more is better [10].

The Kano Model of client contentment (Figure 2) divides service characteristics into three categories: threshold, performance, and excitement. A competitive service meets basic attributes, maximizes performances attributes, and includes as many "excitement" characteristics as possible at a cost the market can bear [11].

Threshold (or basic) characteristics are the expected attributes or "musts" of a product, and do not provide an opportunity for product differentiation. Performance characteristics are those for which more is generally better, and will enhance client contentment. Conversely, an absent or insufficient execution characteristics decreases client contentment [11].

Excitement characteristics are trivial by clients but can result in high levels of clients' contentment, however their absence does not lead to discontentment. Excitement characteristics often contents

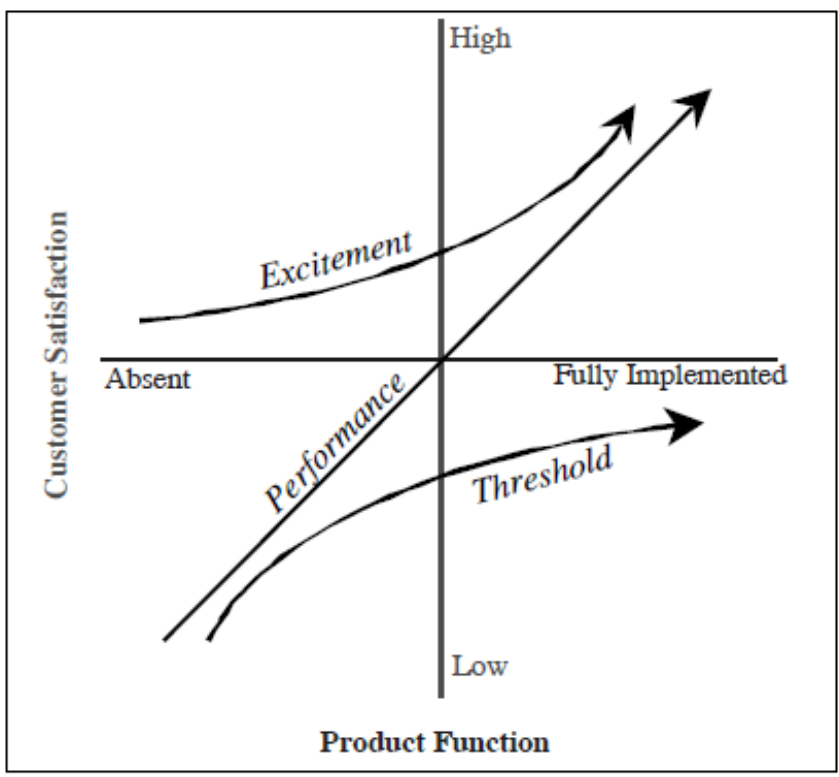

\section{Specialty diversity}

\section{Number of patients}

\section{Transport the patients to the rehabilitation centre}

\section{Location of medical devices maintenance workshop}


potential necessities - real ones of which clients are currently unaware. Services often have characteristics that cannot be rated based on Kano Model. These characteristics are often of little or no consequence to the customer, and do not factor into client rulings [11].

Through applying Kano model to establish VOC; we researched available data sources, and collected data through interviewing the HC.

We Analyzed outcomes from data collection to brainstorm list of features and functionality Questionnaire and to distribute the Questionnaire.

We developed client necessities matrix and record Questionnaire results in the matrix and summarize plot results on Kano Model.

The results were plotted as illustrated in Figure 3:

From Kano model we determined which clients' necessities are considered as a basic (must be) like: comprehensiveness of all patients ages; which one considered as desired quality like: specialty diversity; and which one considered as attractive necessities like: hours of operation to be 24 hours.

Secondly, it is vital to establish technical characteristics in QFD procedure.

In order to achieve clients' necessities, the specialists' personnel had determined the technical characteristics (HOWs). Other parameters for QFD style had also been specified. These parameters contained the prominence weight of clients' necessities and competitive assessment. They were assessed through Kano model.

In this study, task rendering lineaments and weight needed to be developed were set by the engineers during data collection and assessment. The data gathered from case study model has been integrated and analyzed to the QFD pattern. Then, the technical specifications were determined. These shall have the highest relative and absolute weights that should be concentrated on it and enhance it in order to achieve or overtake client anticipations. Finally, the quantitative amount in $\%$ of the performance was deliberated by dividing the actual execution grade to the maximum execution grade.

\section{Results and discussions}

As mentioned earlier, the main goals of this research are to weight the task execution and to distinguish the characteristics that need to be enhanced to ameliorate the performance. This can be accomplished by establishing QFD model.

In building our QFD model, we determined the major phase which was pinpointing the clients' necessities through applying Kano model as shown in Table 1:

In this phase voice of clients were exploited to pinpoint the proportion of significance weighting for every execution directory. The most important performance (must be characteristics) had a value of 10; while the least important performance (attractive characteristics) had a value 1 This proportion was put on the Clients' necessities on the left side of HOQ as shown in Table 1.

It was noticed that comprehensiveness of all patients' ages was the most serious execution part in the design related factors; while existence of bariatric medical devices and ergonomics availability were the least important execution part in the design factors.

The following phase was establishing the technical characteristics for the service provider features as displayed in Table 2; this information was inspired by knowing all the commensurable features of the designers' crew which they were perceive they were related to achieve the specified clients' necessities.

Affinity diagrams were employed to explicate the clients' features; a further row was inserted to display the relationship between these technical characteristics and the overall design as demonstrated in Figure 4.

The roof phase then constructed, it was employed to point out where the technical necessities that characterized technical necessities

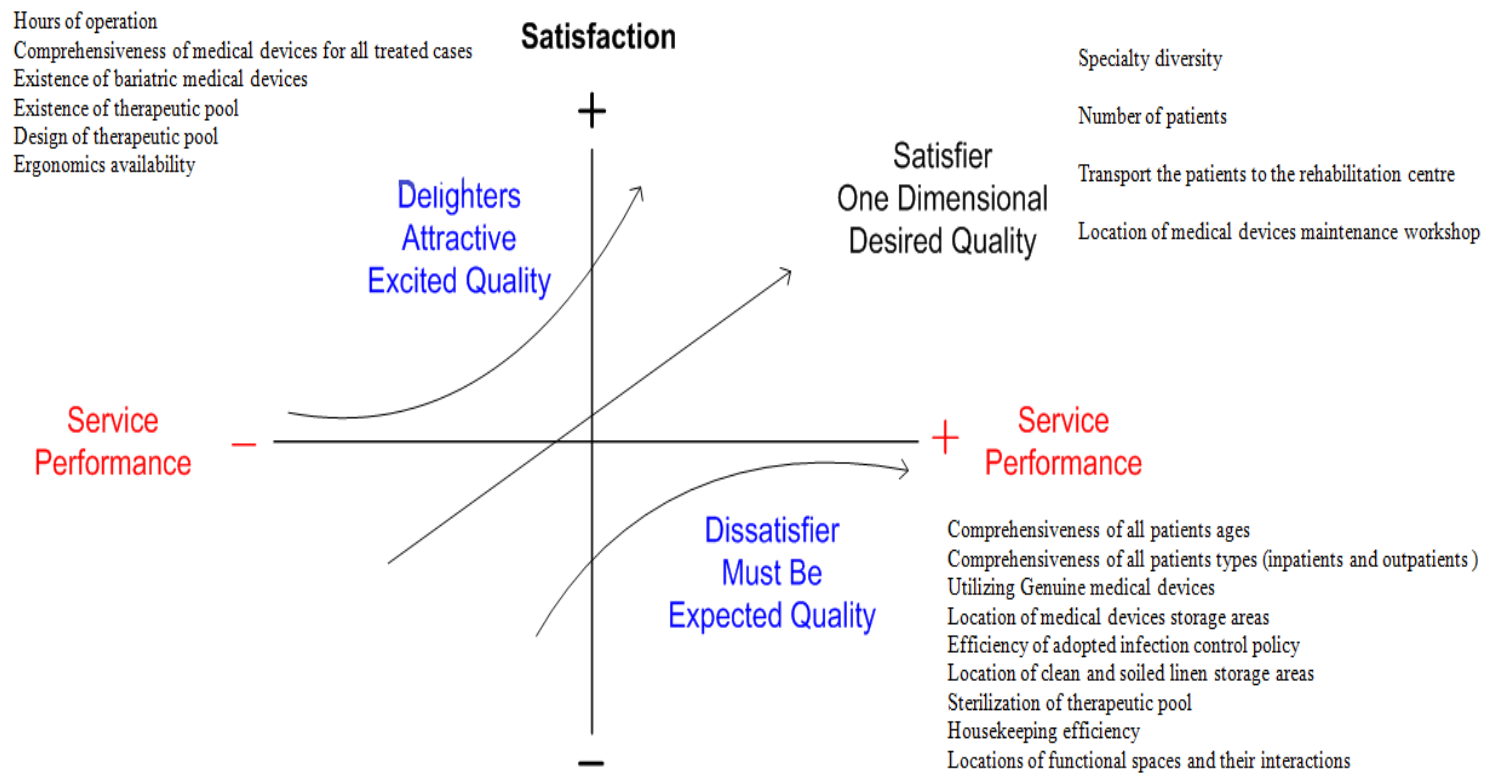

Dissatisfaction

Figure 3. VOC through applying Kano model. 


\begin{tabular}{|c|c|c|c|c|c|c|c|c|c|}
\hline$\uparrow$ & $\uparrow$ & $\uparrow$ & $\uparrow$ & $\uparrow$ & & & & &
\end{tabular}

Figure 4. Technical necessities and its direction of changes.

Table 1. QFD first phase Voice of Client (VOC).

\begin{tabular}{|c|c|}
\hline & Importance weight \\
\hline Specialty diversity & 7 \\
\hline Comprehensiveness of all patients ages & 10 \\
\hline Hours of operation & 4 \\
\hline Number of patients & 6 \\
\hline Comprehensiveness of medical devices for all treated cases & 3 \\
\hline Transport the patients to the rehabilitation center & 5 \\
\hline Comprehensiveness of all patients types (inpatients and & 9 \\
\hline outpatients) & 1 \\
\hline Existence of bariatric medical devices & 8 \\
\hline Utilizing Genuine medical devices & 6 \\
\hline Location of medical devices maintenance workshop & 7 \\
\hline Location of medical devices storage areas & 2 \\
\hline Existence of therapeutic pool & 8 \\
\hline Efficiency of adopted infection control policy & 7 \\
\hline Location of clean and soiled linen storage areas & 9 \\
\hline Sterilization of therapeutic pool & 10 \\
\hline Housekeeping efficiency & 9 \\
\hline Locations of functional spaces and their interactions & 2 \\
\hline Design of therapeutic pool & 1 \\
\hline Ergonomics availability & \\
\hline & \\
\hline
\end{tabular}

improve or hinder each other. It has been constructed through the cells of the roof asking the question: Does improving one necessity yields hindering or enhancement the other technical need?

The roof asserted where focused designers execute enhancement could result in a range of benefits to technical necessities. It converged heed on the negative relationships in the designers' execution. This represented occasions for innovative rejection to be applied.

To establish the roof, the roofs $\mathrm{HC}$ matrices were constructed and then brainstorming was carried to anticipate the average roof that represents all of them as shown in Figure 5:

The delineation matrix set to the right side of HOQ was then stated. It quantified the clients' necessities priorities and the execution of designers. The measures used here were based on questionnaires disbursed on HC.

The delineation matrix was predicated through quantifying the execution $\mathrm{HC}$ which acquired by knowing the execution importance. The interpolation rule was used to acquire the weighting rank for each variable. The results were illustrated in Table 2:
Table 2. Performance importance of HC.

\begin{tabular}{|c|c|}
\hline Specialty diversity & 3.3 \\
\hline Comprehensiveness of all patients ages & 4.7 \\
\hline Hours of operation & 1.8 \\
\hline Number of patients & 2.8 \\
\hline Comprehensiveness of medical devices for all treated cases & 1.3 \\
\hline Transport the patients to the rehabilitation center & 2.3 \\
\hline Comprehensiveness of all patients types (inpatients and & 4.3 \\
\hline outpatients) & 0.3 \\
\hline Existence of bariatric medical devices & 3.8 \\
\hline Utilizing Genuine medical devices & 2.8 \\
\hline Location of medical devices maintenance workshop & 3.3 \\
\hline Location of medical devices storage areas & 0.8 \\
\hline Existence of therapeutic pool & 3.8 \\
\hline Efficiency of adopted infection control policy & 3.3 \\
\hline Location of clean and soiled linen storage areas & 4.3 \\
\hline Sterilization of therapeutic pool & 4.7 \\
\hline Housekeeping efficiency & 4.3 \\
\hline Locations of functional spaces and their interactions & 0.8 \\
\hline Design of therapeutic pool & 0.3 \\
\hline Ergonomics availability & \\
\hline & \\
\hline & \\
\hline & \\
\hline & \\
\hline
\end{tabular}

After the mean arithmetic value for each performance indicator was calculated, the performance indicators (Comprehensiveness of all patients ages and Housekeeping efficiency) were assigned a magnitude of 5 because it had the highest arithmetic average value; the performance indicator (Existence of bariatric medical devices and Ergonomics availability) were assigned a value of 1 because it had the lowest arithmetic average value magnitude. The interpolation method was utilized to find the weight of each performance indicator.

The following phase of HOQ was interrelation matrix, it combines the technical necessities and VOC which should be constructed. The level of interrelation was weighted on a four point scale (High, Medium, Low and None which represent with space) and a symbol expounding this level of interrelation was registered in the matrix cell. To form it, the matrices for $\mathrm{HC}$ were obtained and then brainstorming was conducted to establish the average matrix that represented all of them as shown in Table 3:

Every grade of interrelation weighting was assigned a value, e.g. - High $=9$, Medium $=3$, Low $=1$ and none $=0$. It was twigged from the table that the relationship between "Existence of continuous medical education and training" and "Specialty diversity" is high because when 
Alshami Z (2016) Designing and constructing multi-types of physiotherapy specializations centre through applying a novel approach of quality function deployment (QFD) and Kano Model

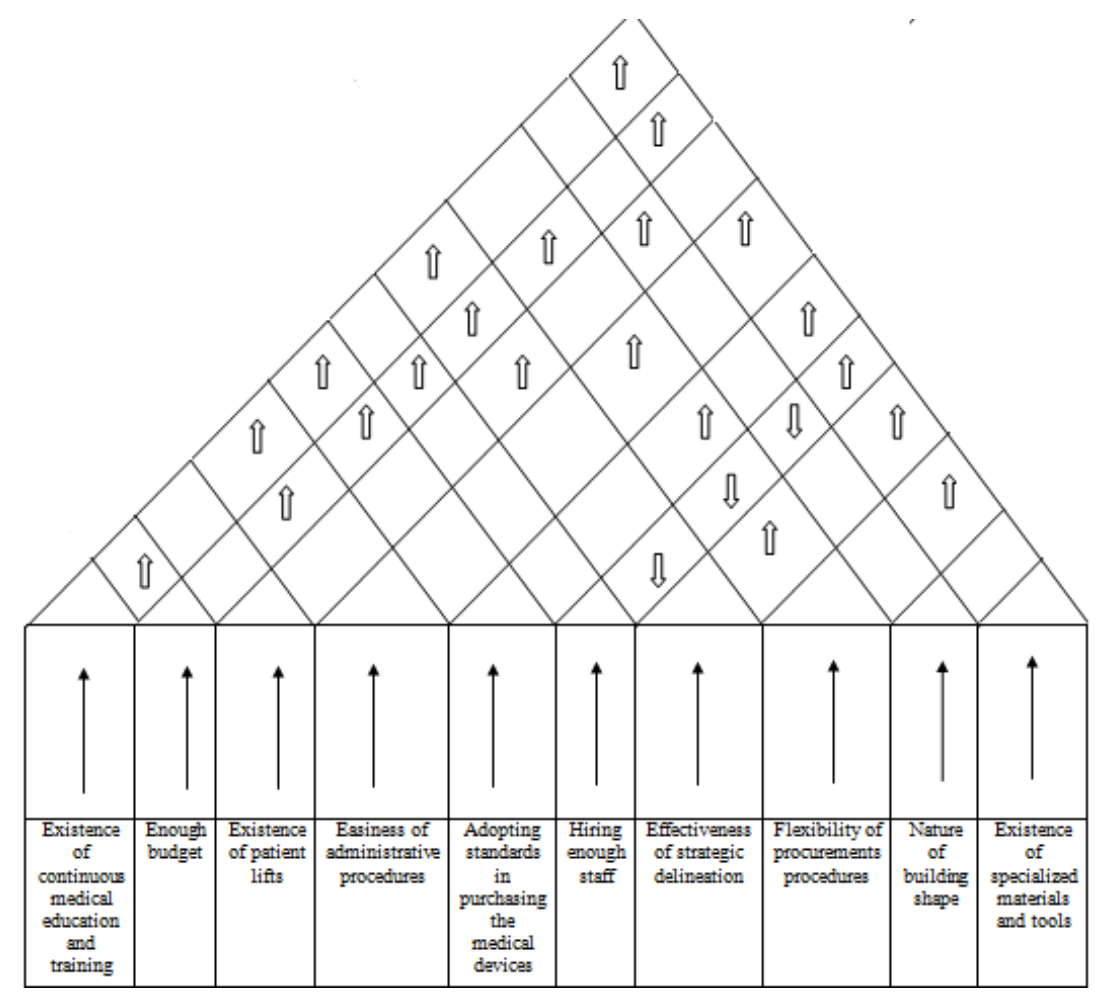

Figure 5. The roof.

Table 3. Interrelation matrix

\begin{tabular}{|c|c|c|c|c|c|c|c|c|c|c|}
\hline & \begin{tabular}{|c|} 
Existence of \\
continuous \\
medical \\
education and \\
training
\end{tabular} & $\begin{array}{l}\text { Enough } \\
\text { budget }\end{array}$ & $\begin{array}{c}\text { Existence of } \\
\text { patient lifts }\end{array}$ & $\begin{array}{c}\text { Easiness of } \\
\text { administrative } \\
\text { procedures }\end{array}$ & $\begin{array}{c}\text { Adopting } \\
\text { standards in } \\
\text { purchasing } \\
\text { the medical } \\
\text { devices }\end{array}$ & $\begin{array}{l}\text { Hiring } \\
\text { enough } \\
\text { staff }\end{array}$ & $\begin{array}{l}\text { Effectiveness } \\
\text { of strategic } \\
\text { delineation }\end{array}$ & $\begin{array}{c}\text { Flexibility of } \\
\text { procurements } \\
\text { procedures }\end{array}$ & $\begin{array}{l}\text { Nature of } \\
\text { building } \\
\text { shape }\end{array}$ & $\begin{array}{c}\text { Existence of } \\
\text { specialized } \\
\text { materials and } \\
\text { tools }\end{array}$ \\
\hline Specialty diversity & $\mathrm{H}$ & $\mathrm{H}$ & & & $\mathrm{H}$ & $\mathrm{H}$ & $\mathrm{H}$ & M & & $\mathrm{M}$ \\
\hline $\begin{array}{l}\text { Comprehensiveness of all } \\
\text { patients ages }\end{array}$ & M & $\mathrm{H}$ & $\mathrm{L}$ & $\mathrm{L}$ & & $\mathrm{H}$ & $\mathrm{H}$ & & M & \\
\hline Hours of operation & & M & $\mathrm{L}$ & M & & $\mathrm{H}$ & $\mathrm{L}$ & & & \\
\hline Number of patients & M & & $\mathrm{H}$ & $\mathrm{L}$ & & $\mathrm{H}$ & M & & $\mathrm{H}$ & \\
\hline $\begin{array}{l}\text { Comprehensiveness of } \\
\text { medical devices for all } \\
\text { treated cases }\end{array}$ & $\mathrm{L}$ & $\mathrm{H}$ & $\mathrm{L}$ & $\mathrm{H}$ & $\mathrm{H}$ & & $\mathrm{H}$ & $\mathrm{H}$ & & $\mathrm{H}$ \\
\hline $\begin{array}{l}\text { Transport the patients to the } \\
\text { rehabilitation center }\end{array}$ & & & $\mathrm{H}$ & & $\mathrm{L}$ & M & $\mathrm{L}$ & & $\mathrm{H}$ & M \\
\hline $\begin{array}{c}\text { Comprehensiveness of all } \\
\text { patients types (inpatients and } \\
\text { outpatients ) }\end{array}$ & & M & $\mathrm{H}$ & $\mathrm{L}$ & M & $\mathrm{L}$ & $\mathrm{H}$ & & M & M \\
\hline $\begin{array}{c}\text { Existence of bariatric medical } \\
\text { devices }\end{array}$ & & $\mathrm{H}$ & & $\mathrm{L}$ & $\mathrm{H}$ & & $\mathrm{M}$ & & & $\mathrm{H}$ \\
\hline $\begin{array}{l}\text { Utilizing Genuine medical } \\
\text { devices }\end{array}$ & & $\mathrm{H}$ & & $\mathrm{L}$ & $\mathrm{H}$ & & M & $\mathrm{H}$ & & $\mathrm{H}$ \\
\hline $\begin{array}{c}\text { Location of medical devices } \\
\text { maintenance workshop }\end{array}$ & & $\mathrm{L}$ & $\mathrm{M}$ & & & L & M & & $\mathrm{H}$ & $\mathrm{L}$ \\
\hline $\begin{array}{c}\text { Location of medical devices } \\
\text { storage areas }\end{array}$ & & & M & & & $\mathrm{L}$ & $\mathrm{L}$ & & $\mathrm{H}$ & $\mathrm{L}$ \\
\hline Existence of therapeutic pool & & $\mathrm{H}$ & $\mathrm{L}$ & & $\mathrm{H}$ & $\mathrm{L}$ & M & & $\mathrm{H}$ & $\mathrm{H}$ \\
\hline $\begin{array}{l}\text { Efficiency of adopted } \\
\text { infection control policy }\end{array}$ & $\mathrm{H}$ & $\mathrm{L}$ & & $\mathrm{M}$ & $\mathrm{H}$ & $\mathrm{L}$ & $\mathrm{H}$ & $\mathrm{H}$ & $\mathrm{L}$ & $\mathrm{M}$ \\
\hline $\begin{array}{c}\text { Location of clean and soiled } \\
\text { linen storage areas }\end{array}$ & & & $\mathrm{L}$ & & & $\mathrm{L}$ & $\mathrm{L}$ & & M & $\mathrm{L}$ \\
\hline $\begin{array}{l}\text { Sterilization of therapeutic } \\
\text { pool }\end{array}$ & & & & & $\mathrm{H}$ & $\mathrm{L}$ & M & $\mathrm{H}$ & & $\mathrm{H}$ \\
\hline Housekeeping efficiency & $\mathrm{L}$ & & & & $\mathrm{H}$ & $\mathrm{H}$ & $\mathrm{H}$ & & $\mathrm{L}$ & $\mathrm{H}$ \\
\hline $\begin{array}{c}\text { Locations of functional } \\
\text { spaces and their interactions }\end{array}$ & & & $\mathrm{H}$ & M & & & M & & $\mathrm{H}$ & \\
\hline Design of therapeutic pool & & $\mathrm{L}$ & & & M & & $\mathrm{L}$ & $\mathrm{H}$ & $\mathrm{H}$ & $\mathrm{L}$ \\
\hline Ergonomics availability & M & M & M & $\mathrm{L}$ & $\mathrm{L}$ & $\mathrm{L}$ & $\mathrm{L}$ & $\mathrm{L}$ & M & $\mathrm{L}$ \\
\hline
\end{tabular}


Alshami Z (2016) Designing and constructing multi-types of physiotherapy specializations centre through applying a novel approach of quality function deployment (QFD) and Kano Model

Table 4. Planned performance rating, amendment factor and the overall weighting of the performance indicators.

\begin{tabular}{|c|c|c|c|}
\hline & $\begin{array}{c}\text { planned } \\
\text { performance rating }\end{array}$ & $\begin{array}{l}\text { amendment } \\
\text { factor }\end{array}$ & $\begin{array}{c}\text { overall } \\
\text { weighting }\end{array}$ \\
\hline Specialty diversity & 4 & 0.175 & 1.225 \\
\hline Comprehensiveness of all patients ages & 5 & 0.06 & 0.6 \\
\hline Hours of operation & 4 & 0.55 & 2.2 \\
\hline Number of patients & 4 & 0.3 & 1.8 \\
\hline Comprehensiveness of medical devices for all treated cases & 4 & 0.675 & 2.025 \\
\hline Transport the patients to the rehabilitation centre & 3 & 0.233 & 1.165 \\
\hline $\begin{array}{c}\text { Comprehensiveness of all patients types (inpatients and } \\
\text { outpatients) }\end{array}$ & 5 & 0.14 & 1.26 \\
\hline Existence of bariatric medical devices & 3 & 0.9 & 0.9 \\
\hline Utilizing Genuine medical devices & 4 & 0.05 & 0.4 \\
\hline Location of medical devices maintenance workshop & 3 & 0.066 & 0.396 \\
\hline Location of medical devices storage areas & 4 & 0.175 & 1.225 \\
\hline Existence of therapeutic pool & 4 & 0.8 & 1.6 \\
\hline Efficiency of adopted infection control policy & 5 & 0.24 & 1.92 \\
\hline Location of clean and soiled linen storage areas & 4 & 0.175 & 1.225 \\
\hline Sterilization of therapeutic pool & 5 & 0.14 & 1.26 \\
\hline Housekeeping efficiency & 5 & 0.06 & 0.6 \\
\hline Locations of functional spaces and their interactions & 5 & 0.14 & 1.26 \\
\hline Design of therapeutic pool & 4 & 0.8 & 1.6 \\
\hline Ergonomics availability & 3 & 0.9 & 0.9 \\
\hline
\end{tabular}

Table 5. Technical priority, competitive benchmarking and targets.

\begin{tabular}{|c|c|c|}
\hline \multirow{10}{*}{$\begin{array}{l}\text { Technical } \\
\text { Priority }\end{array}$} & Existence of continuous medical education and training & 40.83 \\
\hline & Enough budget & 77.746 \\
\hline & Existence of patient lifts & 64.578 \\
\hline & Easiness of administrative procedures & 39.425 \\
\hline & Adopting standards in purchasing the medical devices & 100.015 \\
\hline & Hiring enough staff & 71.106 \\
\hline & Effectiveness of strategic delineation & 85.708 \\
\hline & Flexibility of procurements procedures & 69.42 \\
\hline & Nature of building shape & 99.669 \\
\hline & Existence of specialized materials and tools & 83.121 \\
\hline
\end{tabular}

we adopt the medical training and sending doctors in continuous education training course that will definitely create the diversity of medical specialty and sub-specialty.

The relationship between "Existence of specialized materials and tools" and "Transport the patients to the rehabilitation center" is moderate. When having specialized materials and tools, that will increase the comfort of existing of transportation the patients to the rehabilitation center.

The relationship between "Existence of patient lifts" and "Comprehensiveness of all patients' ages" is low because having patient lifts not necessary means the hospital includes all patients' ages.

\section{- $\quad$ Planned temperance rating}

The planned temperance rating quantified the grade that $\mathrm{HC}$ plan to arrive. They were taken from them. The results of planned performance rating were shown in Table 4:

Regarding the planned performance rating, it was noticed that the lowest HC temperance was found in a lot of performance sections like (Transport the patients to the rehabilitation center, Existence of bariatric medical devices, Location of medical devices maintenance workshop, and Ergonomics availability). The rest of pursuance elements accomplished the performance.

The amendment factor shown in Table 4 was calculated by subtracting the performance result of the $\mathrm{HC}$ from its desired performance result. This difference was divided by 5 to give the amendment factor, for example: the amendment factor for hard duty devices in the hospital was:

$$
\text { (5- 3.3) / } 5=0.175
$$

Regarding the amendment factor, it was remarked that the highest improvement needed to be emphasized was existed in (Ergonomics availability). The lowest improvement needed to be done was existed in (Utilizing Genuine medical devices).

The overall weighting has been obtained by multiplying the importance weighting by the amendment factor as shown in the Table 4, For example; the overall weighting for Number of patients was:

$$
0.3^{\star} 6=1.8
$$

Regarding the overall weighting, it was noticed that (Comprehensiveness of medical devices for all treated cases) had the highest priority to commence with because it had the highest overall weighting. Utilizing genuine medical devices had the lowest priority to commence with because they had the lowest overall weighting.

The targets which are the final section of HOQ were constructed. They represent the illations drawn from the data found in the entire HOQ. They are three parts:

- $\quad$ Technical priority 
The technical priority was calculated by summing the product of the overall weighting shown in table 4 and the interrelations value shown in table 3 as shown in table 5 . For example; the technical priority for Training and instruction was calculated as follow:

$\left[\left(1.225^{\star} 3.0\right)+\left(0.6^{\star} 0.0\right)+\left(2.2^{\star} 0.0\right)+\left(1.8^{\star} 0.0\right)+\left(2.025^{\star} 9\right)+\left(1.165^{\star} 3.0\right)\right.$ $+\left(1.26^{\star} 3.0\right)+\left(0.9^{*} 9.0\right)+\left(0.42^{\star} 9.0\right)+\left(0.396^{*} 1.0\right)+\left(1.2225^{\star} 1.0\right)+\left(1.6^{*} 9.0\right)$ $+\left(1.92^{\star} 3.0\right)+\left(1.225^{\star} 1.0\right)+\left(1.26^{\star} 9.0\right)+\left(0.6^{\star} 9\right)+\left(1.26^{\star} 0.0\right)+\left(1.6^{\star} 1.0\right)+(0.9$ $\left.{ }^{\star} 1.0\right)=83.121$

It was noticed from the previous table that (Adopting standards in purchasing the medical devices) had the highest technical priority so it should be thought of it firstly and trying to solve its problems like having reputable medical equipment sources. Considering the quality as the basic standard of purchasing instead of the price. It was also noticed that (Easiness of administrative procedures) had the lowest technical priority so it was not crucial one.

\section{References}

1. Dursun M, Sener Z, Rawashdeh S (2014) An Integrated DEMATEL-QFD Model for Medical Supplier Selection. International Journal of Mechanical, Aerospace, Industrial, Mechatronic and Manufacturing Engineering, Vol: 8, No: 3, 2014

2. 2. Koken B, Arslan H, Cakmak B (2015) Comparative Spatial Analysis of a Rearranged Hospital Building. International Journal of Civil, Environmental, Structural, Construction and Architectural Engineering 9: 8.
3. Vos L, Groothuis S, Godefridus G, Merode V (2007) Evaluating hospital design from an operations management perspective. Health Care Manage Sci 10: 357-364. [Crossref]

4. Logan J, Radcliffe D (1994) Considering Quality In A Cross- Disciple In Rehabilitation Engineering Service. Proceedings of Nashville Convention Center Nashville, Tennessee June 17-22.

5. Gonzalez ME, Quesada G, Mack R, Urritia I (2005) "Building an activity-based costing hospital model using quality function deployment and benchmarking. Benchmarking: An International Journal 12: 310-329.

6. Ulrich R, Zimring C, Zhu X, DuBose J, Bo Seo H, et al. (2008) A Review of the Research Literature on Evidence-Based Healthcare Design. HERD 1: 61-125. [Crossref]

7. Tsai K, Yeh C, Lo H, Li C, Cheng C, et al. (2008) Application of Quality Function Deployment in Design of Mobile Assistive Devices. Journal of Medical and Biological Engineering 28: 87-93.

8. Gürsel G, Gülkesen K, Zayim N, Arifoğlu A, Gürsel OG, et al. (2012) Investigating Determinants of Medical User Expectations from Hospital Information System. International Journal of Computer, Electrical, Automation, Control and Information Engineering 6: 11 .

9. Akdağ H, Tarım M, Lonial S, Yatkın A (2013) QFD application using SERVQUAL for private hospitals: a case study. Leadership in Health Services 26: 175-183.

10. Koren I (2014) Turning User Requirements Into Technical Features With the House of Quality. STCSN E-Letter 2.

11. www.ucalgary.ca. / design/engg251/First $\% 20$ Year\%20Files/kano

Copyright: (C2016 Alshami Z. This is an open-access article distributed under the terms of the Creative Commons Attribution License, which permits unrestricted use, distribution, and reproduction in any medium, provided the original author and source are credited. 